\title{
Speech Act of Concern on the Academic Performance of Malaysian Foster Children
}

\author{
Cherish How \\ cherishhow@gmail.com \\ Faculty of Languages \& Linguistics, \\ University of Malaya \\ Jariah Mohd Jan \\ jariah@um.edu.my \\ Faculty of Languages \& Linguistics, \\ University of Malaya
}

\begin{abstract}
Language is vital in expressing concern as it allows one to explain their feelings, ideas and behaviour. Teachers and caregivers are concerned about the poor academic performance of foster children as these children have low grades on tests and high dropout rates. Those with poor academic performance might be vulnerable to secure a better life when they leave home. Nevertheless, studies on concern in regards to Malaysian foster children's academic issues from a language perspective are scarce. Hence, this qualitative study uses speech act categories and stages of concern to examine the voices of concern, of teachers and caregivers towards the academic performance of foster children. The data were collected from semistructured interview sessions with teachers and caregivers. Findings reveal that teachers and caregivers are highly concerned about the poor academic performance of foster children as their responses are most prominent in the stage of refocusing. They attempted to reach out to address foster children's academic needs by giving suggestions. However, they face challenges in addressing these children's academic needs and issues. Representative act is highly utilised by teachers and caregivers to describe, report or explain about problems in trying to help the children. This study contributes to the area of speech acts on concern especially on the academic performance of foster children in Malaysia.
\end{abstract}

Keywords: Speech act of concern; stages of concern; foster children; academic needs; Malaysia

\section{INTRODUCTION}

Language is significant as it allows speakers to express emotion such as concern. Concern has been addressed in Hall and Hord's (1987) concern-based adoption modal, but individual's choice of words (i.e. linguistics aspect) to voice concern has been neglected. Additionally, studies which offer a systematic analytical framework of concern from a pragmatic perspective, specifically on the language of concern of teachers and caregivers towards the academic performance of foster children, are scarce. Hence, without analysing the linguistic aspect, teachers and caregivers' concern might not be fully comprehended.

Foster children are children who have been receiving protection from the government because they live separately from their parents due to abandonment, neglect or abuse (Azizah Mohd. \& Nadhilah Abdul Kadir, 2012). These children are placed in foster care until they reach the age of 18 (Child Act, 2001). Previous studies have shown that many foster children perform poorly in tests or dropout from school because they are not able to cope with their studies (Olsen \& de Montgomery, 2018; Segermark, 2017; Barnow et al., 2015; Berger et al., 
2015; Zetlin, Weinberg, \& Kimm, 2004). Those with poor academic performance would have fewer chances to pursue tertiary level education or obtain better job opportunities (Malaysia Education Blueprint, 2013-2025). Without a secured job, foster children may encounter challenges to be self-reliable financially once they leave foster care system as they are left without any form of support system (Bruskas, 2008).

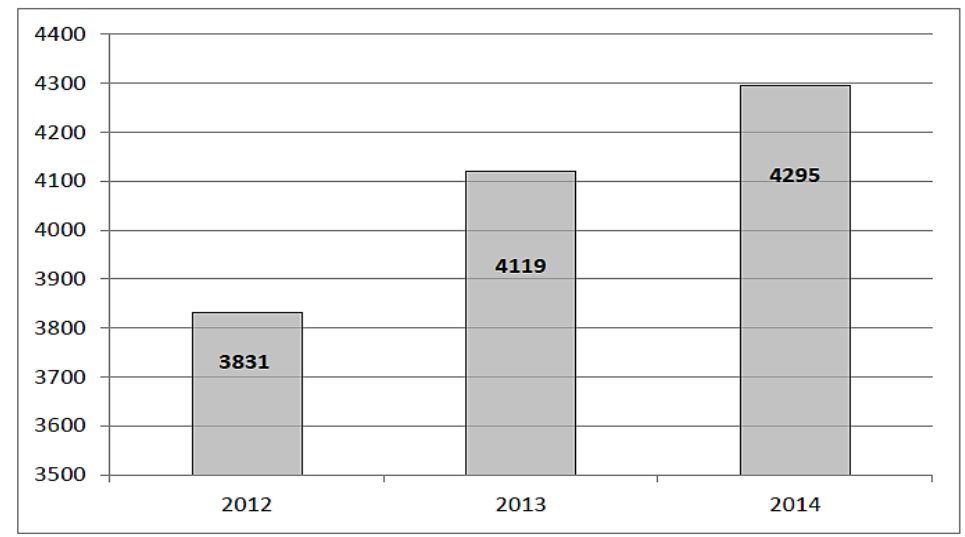

FIGURE 1. Numbers of Foster Children in Malaysia (2012-2014)

Figure 1 illustrates the increasing number of foster children who are placed in governmental foster homes from the year 2012 to 2014 (Laporan Statistik Jabatan Kebajikan Masyarakat, 2014, p. 248). In other words, more and more children are being placed in foster care and they are the future generations of our nation. However, their poor upbringing due to family background and poor academic performance may affect their future. Therefore, this paper examines the voices of concern of teachers and caregivers towards the academic performance of foster children via Searle's (1976) speech act categories and Hall and Hord's (1987) stages of concern. By doing so, this study could highlight on concern among teachers and caregivers and provide a specific analytical framework to examine speech act of concern.

Austin (1962) defines speech act as "action performed when an utterance is produced" and claims that speech acts consist of three levels: locutionary act, illocutionary act and perlocutionary act. In 1976, Searle further developed five categories of speech acts based on Austin's (1962) illocutionary act, namely representative act, directive act, commissive act, expressive act and declarative act.

Various studies on the types of speech act were carried out in the field of pragmatics such as speech act of refusals (e.g. Shishavan \& Sharifian, 2016; Kreishan, 2018), condolences (e.g. Sharif et al., 2018), congratulations (e.g. Aziz et al., 2018), requests (e.g. Rezvani et al., 2014) and apologies (e.g. Parsa \& Jariah Mohd. Jan, 2016). However, to date, not much attention has been given to the study on speech act of concern. It is still unclear how concern is categorised in reference to the five categories of speech act.

\section{RELATED STUDIES ON THE NOTION OF CONCERN}

Concern refers to the "composite representation of feelings, preoccupation, thought and consideration given to a particular issue or task" (Hall \& Hord, 1987, p. 61). Such a composite representation of feeling also involves "the mental activity composed of questioning, analysing, re-analysing, considering alternative actions and reactions, and anticipating consequences" (Hall, George, \& Rutherford, 1979, p. 5).

The notion of concern has appeared in studies of pragmatics, psychology and education. In the study of pragmatics, for instance, the expression of concern emerged as one 
of the findings in Carretero et al.'s (2015) study. Despite the fact that expression of concern was found in Carretero et al.'s (2015) data, the emphasis was not on analysing the way concern is voiced from a pragmatic perspective. Instead, their focus was on examining the different sub-types of expressives among university students through an online-interaction. Correspondingly, Kampf's (2016) study indicates the feature of concern emerged in examining the speech act of solidarity in political discourse. In his study, politicians express concern to promote solidarity in the speech acts of blessing and wishing. Although studies the two studies, Carretero et al. (2015) and Kampf (2016) show that concern is mainly expressive, concern could also be directives in certain situation. For instance, in Kuang's (2015) study, the expression of concerns emerged through directives as one of the semantic functions used by speakers to express condolences. Thus, speech act of concern need not solely be classified as expressive act. Thus, there is a need to explore the speech act of concern as it can be classified as more than one speech act.

In terms of a methodological aspect in the field of psychology, Rhee et al. (2013) conducted a study on concern and disregard for others among children. Their findings show that language skills are important in developing children's concern. They found that children with higher language skills display or express more concern to others if compared to children with lower language skills (Rhee et al., 2013, p. 16). Yet, no specific criteria of analysis were applied as an analytical framework to analyse the language of concern by Rhee et al. (2013) in the field of psychology.

Apart from pragmatics and psychology, concern was also examined in the field of education with priority not given to students' concern. Hall and Hord (1987) examined teachers' concerns towards modification in the implementation process of innovation in school. In their study, Hall and Hord (1987) developed Concerns-Based Adoption Model (CBAM) which involves the seven stages of concerns, levels of use and innovation configurations. However, they focus more on examining concern on teachers' needs instead of students' needs (Straub, 2009). Hence, it is necessary to examine the concern of students as they are the receivers of knowledge in school.

Although the expression of concern appears in these studies, there are no specific criteria to analyse the linguistics aspect as to how concern is voiced. Studies on speech act of concern on academic performance of students from foster care in Malaysia are lacking despite their poor performance (Chan, 2013). As such, there is a need to examine concern of teachers, caregivers and foster children, from a linguistic perspective.

\section{CONCERNS-BASED ADOPTION MODEL (CBAM): STAGES OF CONCERN}

It is necessary to describe the developmental levels of concern which were initially introduced by Fuller (1969), before Hall and Hord (1987) developed Concerns-Based Adoption Model. The three developmental levels consist of self, task and impact concern.

TABLE 1. Developmental Levels of Concern (Fuller, 1969)

\begin{tabular}{ll}
\hline & \multicolumn{1}{c}{ Fuller's (1969) Developmental Levels of Concern } \\
\hline Impact: & Teachers' concern regarding students' outcomes \\
Task: & Regular problems of a teaching task \\
Self : & Teachers' concern in managing new implementation programme in school \\
\hline
\end{tabular}

Drawing from Fuller's (1969) developmental levels of concern (see Table 1), Hall and Hord (1987) further developed Concerns-Based Adoption Model (CBAM). CBAM describes, measures, and explains teachers' concern towards change in the implementation process of innovation in school. CBAM also contains three key diagnostic tools: stages of concern, 
levels of use and innovation configurations. The three key diagnostics tools in CBAM may be used individually or in various combinations (Hall \& Hord, 2006).

From an analytical viewpoint in this study, 'stages of concern' (Table 2) in CBAM allow the analysis of the degree of teachers and caregivers' concern on the academic performance of foster children. At the same time, seven stages of concern provide more indepth analysis on concern compared to Fuller's (1969) three developmental levels. Table 2 provides examples of expressions of concern introduced by Hall and Hord's (1987) study.

TABLE 2. Stages of Concern (Hall \& Hord, 1987)

\begin{tabular}{|llll}
\hline \multicolumn{2}{l}{ Stages of Concern } & & \multicolumn{1}{c}{ Descriptions } \\
\hline 5 & Stage of Refocusing & $>$ & $\begin{array}{l}\text { to identify suggestions given or actions taken by teachers and } \\
\text { caregivers to improve the academic performance of foster children }\end{array}$ \\
\hline 4 & Stage of Consequence & $>$ & $\begin{array}{l}\text { to investigate collaboration of teachers and caregivers in addressing } \\
\text { the academic needs of foster children }\end{array}$ \\
\hline 3 & Stage of Management & $>$ & $\begin{array}{l}\text { to explore the issues faced by teachers and caregivers while } \\
\text { addressing the academic needs of foster children }\end{array}$ \\
\hline 2 & Stage of Personal & $>$ & $\begin{array}{l}\text { to identify teachers' and caregivers' personal feelings towards foster } \\
\text { children's academic performance }\end{array}$ \\
\hline 1 & Stage of Informational & $>$ & $\begin{array}{l}\text { to identify teachers' and caregivers' willingness to learn more about } \\
\text { the academic problems of foster children }\end{array}$ \\
\hline 0 & Stage of Awareness & $>$ & $\begin{array}{l}\text { to recognise how aware teachers and caregivers are towards the } \\
\text { academic problems of foster children }\end{array}$ \\
\hline
\end{tabular}

From an analytical perspective, there are studies which have applied CBAM to examine concern of school teachers towards the implementation of computers in teaching (e.g. Hord et al., 1987; Newhouse, 2001; Wang, 2014). For instance, Hall and Hord (1987) tested CBAM using questionnaires by correlating teachers and college professors' concerns regarding the educational transformation. Based on their findings, the respondents either go through every stage of concern or skip through one or two stages before proceeding to the next stage when voicing concerns (Hall \& Hord, 1987). Additionally, Wang (2014) also applied this model to examine teachers' concern on the new curriculum implementation via interviews and questionnaires. Based on the studies done by previous researchers (e.g. Hord et al., 1987; Newhouse, 2001; Wang, 2014), their results show that CBAM allows them to determine teachers' degree of concern and actions towards educational transformation. While CBAM was mainly developed to examine concern in the academic context, this model could be also used to examine concern in other contexts (Straub, 2009). Also, surveys, interviews (Straub, 2009) or focus group discussions (Rhodes et al., 2010) can be employed to examine an individual's concern.

Furthermore, stages of concern are organised from the lowest to the highest stage, which is from the stage of awareness to the stage of refocusing. Charambous (2004) assumes the stages of concern are hierarchical as the respondents' concerns in his study in the preceding stage leads to their concerns in the succeeding stage. Obviously, via Charambous' (2004) assumption, the hierarchical stages of concern do exist. On the contrary, Straub's (2009) finding shows that the stages of concern are not hierarchical. In fact, respondents may skip a stage when voicing concern and many of them did not reach the highest stage of concern. Similarly, Anderson (1997) indicates that respondents' concern in one stage does not automatically lead to the later stage. Although it is possible, it may not necessarily be a developmental progression of the stages of concern. Therefore, additional research in probing into the hierarchical stages of concern is needed in order to enhance our understanding of the evaluation of concern. 
Apart from that, CBAM has also been criticised by several researchers. Straub (2009) states that CBAM put more emphasis on teachers' concerns rather than students' concerns. He highlights that it is vital to explore the students' needs as they are the receiver of educational input. Likewise, in Malaysia, more studies were done on teachers' concern on the outcome of adopting ICT (e.g. Thang et al., 2014; Norazila Abd Aziz, 2017) instead of student's concern on their academic needs, particularly in the linguistics aspect. Moreover, without analysing the linguistics aspect, affective concern would not be fully understood from a pragmatic perspective.

\section{METHOD}

The analytical framework in this study was a combination of Hall and Hord's (1987) stages of concern, and Searle's (1976) speech act categories, as shown in Figure 2. These two forms of analysis served to analyse the language of concern among teachers and caregivers in this study. Specifically, this study did not involve educational innovation or implementation of new programs in schools. Therefore, 'levels of use' and 'innovation configurations' were not applied as analytical tools.

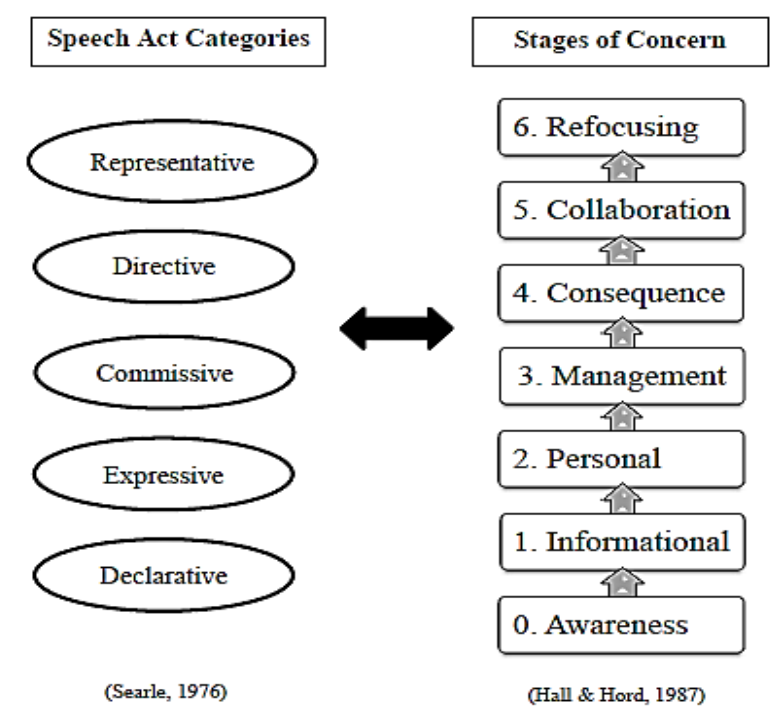

FIGURE 2. Analytical Framework of Concern

The analytical framework of concern in Figure 2 assisted this study to analyse the speech act of concern. The association of the five categories of speech acts into the respective stages of concern served to identify the realisation patterns of speech act of concern. The degree to how concerned teachers and caregivers were towards the academic performance of foster children was also examined using this analytical framework with a combination of the two frameworks as a single analytical framework. The following sub-sections provide individual discussion on speech act categories and stages of concern.

\section{SPEECH ACT CATEGORIES}

Searle's (1976) five categories of speech act which assisted this study to analyse the language use of teachers and caregivers while voicing concern are provided in this section. These speech act categories are:

i. Representative act : serves to present speaker's thoughts or beliefs

ii. Directive act : serves to direct hearer to perform an action

iii. Commissive act : expressions that commit the speaker's forthcoming action 
iv. Expressive act

v. Declarative act
: expresses the speaker's feeling or psychological states

: performed by certain authorities in a specific context

\section{STAGES OF CONCERN}

This section describes how Hall and Hord's (1987) stages of concern assisted the analysis of this study. Table 3 illustrates the adaptation of Hall and Hord's (1987) stages of concern for the purpose of analysis for this study.

TABLE 3. Adaption from Hall and Hord's (1987) Stages of Concern

\begin{tabular}{|llll}
\hline \multicolumn{2}{l}{ Stages of Concern } & \multicolumn{1}{c}{ Descriptions } \\
\hline 5 & Stage of Refocusing & $>$ & $\begin{array}{l}\text { to identify suggestions given or actions taken by teachers and } \\
\text { caregivers to improve the academic performance of foster children }\end{array}$ \\
\hline 4 & Stage of Consequence & $>$ & $\begin{array}{l}\text { to investigate collaboration of teachers and caregivers in addressing } \\
\text { the academic needs of foster children }\end{array}$ \\
\hline 3 & Stage of Management & $>$ & $\begin{array}{l}\text { to explore the issues faced by teachers and caregivers while } \\
\text { addressing the academic needs of foster children }\end{array}$ \\
\hline 2 & Stage of Personal & $>$ & $\begin{array}{l}\text { to identify teachers' and caregivers' personal feelings towards foster } \\
\text { children's academic performance }\end{array}$ \\
\hline 1 & Stage of Informational & $>$ & $\begin{array}{l}\text { to identify teachers' and caregivers' willingness to learn more about } \\
\text { the academic problems of foster children }\end{array}$ \\
\hline 0 & Stage of Awareness & $>$ & $\begin{array}{l}\text { to recognise how aware teachers and caregivers are towards the } \\
\text { academic problems of foster children }\end{array}$ \\
\hline
\end{tabular}

The analysis begins by evaluating teachers and caregivers' degree of concern based on the emergence and salient patterns of concern through lexical choice such as words, phrases or utterances via Hall and Hord's (1987) seven stages of concern. The arrangement of stages from the lowest (i.e. awareness) to the highest (i.e. refocusing) is shown by a vertical arrow. The lowest stage was represented with a zero as there could be little or no concern about the issue addressed. Next, these stages along with Searle's (1976) speech act categories were used in analysing speech act of concern. This step is to identify how the categories of speech act relate with each stage of concern. The percentages were manually calculated respectively according to the number of teachers and caregivers who used the categories of speech acts and stages of concern. Then, the data were tabulated into a number of tables for comparison as well as to gain a summary of the findings.

\section{DATA}

This study involved 26 teachers and 6 caregivers. The teachers from a semi-urban secondary school located in Klang Valley were selected based on purposive sampling method. The criteria for selection are teachers who either have experienced teaching students from foster home or are currently teaching these students. On the other hand, 6 caregivers, who are all at management position from three different foster homes, were selected based on snowball sampling method.

This study is not without limitation as permission to observe teachers and caregivers' interaction with foster children either in classroom or at foster home was not granted. Only semi-structured interview sessions were allowed to be conducted by the researchers for the purpose of this research. Semi-structure interview questions were constructed based on the following criteria: 
i. Knowledge question (to ask about foster children's academic performance)

ii. Experience question (to identify teachers' and caregivers' experience in relation to addressing foster children's academic needs and issues)

iii. Opinion / value question (to get teachers' and caregivers' opinion on how to help the foster children academically)

iv. Background question (to obtain teachers' and caregivers' background profile)

The overall duration of the interview sessions was approximately 11 hours and 41 minutes which consists of 8 hours and 19 minutes with teachers and 3 hours and 22 minutes with caregivers. The interview transcripts are the main data as this paper aims to identify the realisation patterns of speech act of concern. In this paper, teachers were coded as ' $\mathrm{T}$ ' and caregivers as ' $\mathrm{G}$ ' in the excerpts. The interviews were transcribed based on the adaptation of Jefferson $(1984 ; 2004)$ transcription convention.

TABLE 4 Transcription Conventions (Jefferson, 1984, 2004)

\begin{tabular}{lll}
\hline \multicolumn{1}{c}{ Symbol } & \multicolumn{1}{c}{ Name } & Function \\
\hline$/$ & Slash & To indicate the breaks between utterances \\
\hline$?$ & Question mark & $\begin{array}{l}\text { To indicate the rising pitch or demonstrate the way one } \\
\text { poses questions }\end{array}$ \\
\hline underline & Underlined text & To emphasise on certain words or phrases in speech \\
\hline$::$ & Colon(s) & To indicate the prolongation of sound \\
\hline$(\mathrm{XXX})$ & $\begin{array}{l}\text { Single parenthesis } \\
\text { with triple X }\end{array}$ & To indicate unclear speech \\
\hline$(($ italic text $))$ & Double parentheses & To indicate non-verbal activity \\
\hline
\end{tabular}

\section{FINDINGS: REALISATION PATTERNS OF SPEECH ACT OF CONCERN}

Each category of speech act in each stage of concern (ranging from lowest to the highest stage) is provided in order to demonstrate the realisation patterns of speech act of concern. This is necessary in order to identify the different stages of teachers' and caregivers' concern on the academic performance of foster children during interview. The following section provides the analysis of teachers' and caregivers' responses.

\section{STAGE OF AWARENESS}

It was possible to identify teachers and caregivers' awareness towards the academic needs and issues of foster children in the stage of awareness. Representative act is the only category of speech act that appears in the participants' responses in this stage.

\section{REPRESENTATIVE ACT}

The following excerpt is a sample of teacher's response in the stage of awareness using representative act to assert, state and describe the low level of comprehension of foster children in her class.

\section{Excerpt 1}

[1] T6: Yes / because they don't understand a thing that I / you know

[2] the first day I entered Form 2V / I had / I have three of them /

[3] and they::: they don't even understand a simple / you know /

[4] it's like you're teaching a primary school / 
T6 asserts that foster children in her class require special educational assistance in learning English as they have low proficiency in this subject. Her concern that these children do not seem to understand English language can be observed in the negative statement "they don't understand a thing" in line 1. She highlights her concern using the term 'a thing' (line 1) as low level of comprehension in English might be one of the reasons of foster children's poor academic performance. This is because English language is one of the core subjects in school and in national examinations such as UPSR (primary school assessment), PT3 (Form 3 assessment) and SPM (Malaysian Certificate of Education), where every student needs to undergo in order to test their knowledge, value and skill before proceeding to the next level of education. Hence, there is a necessity for students to perform well in this subject. However, based on T6 in Excerpt 1, foster children are having difficulty to comprehend simple sentences in English in a way indicates that they have poor performance in this subject and it is a concern.

Furthermore, T6 expresses disbelief in the problems foster children encounter in understanding words and constructing sentences in English when she employs the adverb 'even' (line 3). This adverb reinforces her concern on foster children's poor performance in English as according to Bennett (1982), the adverb 'even' can be used to emphasise or stress on a surprising truth. The situation where foster children do not understand a simple sentence structure in English at Form 2 lower secondary level might came as a surprise for T6. She further describes the low proficiency level with reference to primary school students (line 4) in order to denote their low performance level. Therefore, T6's response is categorised in the stage of awareness for being aware of the poor academic performance of foster children in her class.

\section{STAGE OF INFORMATIONAL}

In the stage of informational, teachers and caregivers' willingness to learn more about the academic problems of foster children can be identified by the way they approach these children. Similar to the stage of awareness, only representative act can be found in this stage.

\section{REPRESENTATIVE ACT}

An example of response in the stage of informational with the use of representative act can be seen in Excerpt 2 where a teacher asserts and states her act in caring for foster children.

\section{Excerpt 2}

[1] T6: They need someone to talk to / because if you are / if you don't

[2] talk to them / you will / you won't know what is inside them /

I always ask them / dah makan? / have you eaten? /

T6 asserts that there is a need to probe into foster children's problems as they are mostly reluctant to share if not being approached (line 1). T6's initiative in learning more about foster children's needs in school can be observed in the statement "I always ask them" (line 3). The teacher's response is classified in the stage of informational as her act reflects her effort and willingness to care for the problems encountered by foster children. This also shows that while in school, it is the teachers' responsibility to care for foster children. Therefore, by asking them about lunch, T6 shows concern towards the foster children as they need to eat well in order to stay focused in class. 


\section{STAGE OF PERSONAL}

In the stage of personal, teachers and caregivers use expressive act to express their personal feelings about the poor academic performance of foster children.

\section{EXPRESSIVE ACT}

A sample of expressive act in the stage of personal can be seen in Excerpt 3 .

\section{Excerpt 3}

[1] G5: we feel very sad / we feel very sorry /

G5 expresses her sympathy about the poor academic performance of foster children with the verb rasa (feel) as well as the adjectives 'sad' and 'sorry'. G5 employs the explicit intensifier 'very' (line 1) to further highlight the adjectives in order to strengthen the illocutionary force of her feelings of sympathy. Such a usage could be considered as her expression of affective empathy towards foster children's academic struggles. G5's expression of sympathy about the foster children's poor academic performance might in a way show that she cares for these children.

\section{STAGE OF MANAGEMENT}

In the stage of management, teachers and caregivers use representative act to describe the issue they encounter while addressing the academic needs of foster children as well as directive act to suggest or request for support.

\section{REPRESENTATIVE ACT}

A sample of a teacher's response with representative act can be observed in Excerpt 4 when the teacher describes the difficulty she has while trying to get to know more about the foster children in her class.

\section{Excerpt 4}

[1] T2: I was told that I have one er::: student from the rumah kebajikan /

[2] because the thing is I::: even though I'm a class teacher /

[3] I don't have a lot of time in the class /

In responding to a question posed regarding the number of foster children in her class, T2 prolongs the pause filler /er/ and personal pronoun 'I' (lines 1 and 2). Such prolongations could show her uncertainty or trying to 'mitigate' (Lakoff, 1975) on her awareness towards the background of foster child. The reason of her uncertainty or mitigation is revealed when she describes her predicament to spend more time with the foster child despite being a class teacher as the duration in class is limited, which is evident in the utterance "I don't have a lot of time in the class" (line 3). In a way, she could be trying to reach out for more time to be spent with the foster children in her class. T2's response could be categorised in the stage of management for sharing the problems as she lacks class time with her students despite being a class teacher.

\section{DIRECTIVE ACT}

The following exchange illustrates the use of directive act in the stage of management. 


\section{Excerpt 5}

[1] G5: In terms of er support / erm what I see / what I see they always

[2] search for our mistakes / selalu / they're not helping much / always

[3] more to the mistakes that we do / help us / I every time when I see

[4] them / we don't want anything / we started by ourselves /

Due to the challenges G5 encounters in addressing the needs of foster children, she requests for cooperation of the social welfare management system in the form of directive. The stage of management can be observed from the utterance "they're not helping much" (line 2), which denotes her dismay with the social welfare system on not giving the sufficient support when needed. Additionally, G5 employs the adverb 'always' (line 1) and code switches to Malay selalu (always) (line 2) to reinforce her discontentment with the social welfare agency. The directive act is identified when G5 utters "help us" (line 3) to request for support from the social welfare agency in an overt manner in order to address the needs of their foster children. Her request could also be an appeal for help as they are in need of support such as in terms of finance.

\section{STAGE OF CONSEQUENCE}

In this stage, factors that affect the academic performance of foster children can be identified from the teachers and caregivers' use of representative act.

\section{REPRESENTATIVE ACT}

In the following sample of response, a caregiver employs representative act to state, exemplify and illustrate her view that parents could influence foster children's academic performance.

\begin{tabular}{|c|c|}
\hline Excerpt & \\
\hline [1] G2: & It's the mindset of the child / erm there are certain children who just \\
\hline [2] & feel that / I have one boy okay / he'll openly tell you / my dad never \\
\hline [3] & study and he is doing well / and he told me / I don't have to study \\
\hline [4] & because it's okay / you'll still do well in life / the father gives him \\
\hline [5] & advice every time the father calls / so that kind of a thing / even though \\
\hline [6] & we are here in their life on a daily basis / erm a father's word / a parent's \\
\hline [7] & word is still the most powerful / so yeah / not much we can do / \\
\hline
\end{tabular}

In Excerpt 6, G2 states that parent's advice could demotivate a foster child to study. To justify her statement, she exemplifies a real-life situation of a foster child to show that she is aware that parents can leave a negative impact on the children. She quotes the foster child's response "I don't have to study because it's okay, you'll still do well in life" (lines 3 and 4) to illustrate the consequence by the parent's negative influence on the child. Moreover, G2 employs the intensifier 'most' (line 7) to reinforce the adjective 'powerful' in order to emphasise the strong effects a parent's advice has on a child's thought. Hence, a foster child's poor academic performance could have derived from a parent's negative influence. G2's concern on such an influence is classified in the stage of consequence. 


\section{STAGE OF COLLABORATION}

The collaborative act of teachers and caregivers with others can be observed based on their descriptions using representative act and their assurance in addressing the academic needs of foster children using commissive act.

\section{REPRESENTATIVE ACT}

The following excerpt is a sample of response from a caregiver who uses representative act in the stage of collaboration.
Excerpt 7
[1] G2: I have private tutors for them / okay / we pay them hourly / salary /
[2] the reason why we've seen they're volunteers who come and work /
[3] they're not as stable / but when you pay someone / they come in
[4] because you're paying them money / yeah commitment / so it's
[5] about two students to one tutor/and the core subjects basically
[6] or the ones subjects that we get / then we work with them / that's
[7] the tutor / on the daily basis of course the staff work with them /

G2, in Excerpt 7, states her collaboration with private tutors with the intention to improve the poor academic performance of foster children. In line 3, G2 adopts the adjective 'not as stable' (line 3 ) to indicate the ineffectiveness of volunteers as they are not committed in helping foster children. As a result, G2 states that she hires tutors for foster children due to the lack of commitment from voluntary tutors. She employs the personal pronoun 'I' (line 1) to indicate self-reference in which as a manager of the foster home, she takes charge in hiring tutors for her foster children. Subsequently, she orients to group-reference when she uses the personal pronoun 'we' (lines 1, 2 and 6) to indicate her colleagues and her involvement in collaborating with the tutors in order to be involved with the academic progress of foster children. G2's response falls in the stage of collaboration when she repetitively utters "work with them" (lines 6 and 7) to highlight that she has worked with the private tutors to assist the foster children in their academic pursuits.

\section{COMMISSIVE ACT}

Apart from representative act, commissive act can also be seen in the stage of collaboration. Excerpt 8 is a sample of a teacher's response with the use of commissive act.

\section{Excerpt 8}

[1] T18: Dia perlukan orang lain / terutamanya guru untuk membantu mereka / he/she needs people other / especially teacher for helping them they need someone else / especially teachers to help them

[2] dan kita memang kita bercadanglah pihak-pihak sekolah / and we indeed we suggest PARTICLE lah parties school / and we actually suggested to our school community pihak PIBG baru ni bermesyuarat

party just this meeting / we plan to
parents-teachers association just had meeting recently / we are planning to mengadakan konsep mentor-mentee / dan Insha'Allah pelajar-pelajar ini kita have concept / and Praise God students these we have the mentor-mentee concept / and Praise God these students akan kekalkan / kita akan tetapkan er ibubapa angkat di sekolah / will be retained / we will set will be retained / we will set 
T18 ensures that teachers should help foster children in monitoring their academic progress in line 1 kita akan tetapkan er ibubapa angkat di sekolah (we will set foster parents in school). T18 uses the modal verb akan (will) (line 5) to ensure that the school will provide each foster child with a teacher who acts as a mentor in assisting them academically. Moreover, kita (lines 2, 3, 4 and 5) denotes the collective pronoun (Steffans \& Haslam, 2013) which represents the school and parents committee working together as a group to monitor the academic performance of foster children. T18's response falls in the stage of collaboration as the act of collaboration in addressing the needs of foster children can be seen from the verb bermesyuarat (meeting) in line 3.

\section{STAGE OF REFOCUSING}

In the stage of refocusing, a total of three categories of speech act emerged from teachers and caregivers' responses, namely representative act, directive act and commissive act.

\section{REPRESENTATIVE ACT}

A sample of representative act from a caregiver in the stage of refocusing can be seen in the following excerpt where the caregiver affirms and indicates the need for monitoring foster children.

\section{Excerpt 9}

[1] G2: Very / because when I do go back home / erm if you notice we have

[2] CCTVs here right? / we've CCTVs / so / the minute I go back home / every fifteen twenty minutes I'll be checking/

In Excerpt 9, G2 affirms that there is a constant monitoring on her foster children despite her not being at the foster home. G2 employs the intensifier 'very' (line 1) to highlight her involvement in monitoring her foster children. She further exemplifies by showing the CCTVs (i.e. closed-circuit television system) or video surveillance in the foster home, simultaneously with a tag question "if you notice, we have CCTVs here right?" (lines 1 and 2). Additionally, she also indicates the duration of time "every fifteen twenty minutes" (line 3) she keeps track of these children. Such an act denotes her concern and care for her foster children, which therefore could be categorised in the stage of refocusing for taking action to address the need of foster children (i.e. the need for attention).

\section{DIRECTIVE ACT}

A sample of directive act in the stage of refocusing is shown in the following excerpt where the teacher gives suggestions with the aim of addressing their academic needs.

\section{Excerpt 10}

[1] T2: The first thing I guess er::: we should just give them some

[2] diagnostic tests / right? / to know that where are they weak

[3] at / weak in / maybe in Maths or English / but I guess is is most

[4] of the core subjects / then from there / these students should

[5] be given er::: tuitionlah / right? / maybe extra books /

[6] where::: time is allocated for them or::: they do it at home

[7] and they give it to the teacher / doesn't matter /

[8] The tuition centres are making good money / because they they

[9] see something in return / you know / and er::: I hope this can

[10] be applied to these students where the government has some 
[11] allocation given and they can / you know / help them / they are

[12] good students / their discipline wise they are fine / just pushing

[13] up in their education level will make them a fine student /

T2 uses the modal verb 'should' (line 4) to suggest the necessity of providing foster children with diagnostic tests, extra books and tuition classes. However, she also mitigates the illocutionary force of her suggestions with hedges 'I guess' (line 1) and 'maybe' (line 5). While suggesting, T2 expresses her aspiration to improve the academic performance of foster children with the pragmatic marker 'I hope' (line 9). The verb 'hope' could also be considered as her uncertainty on whether the government would agree with her suggestion to provide financial support for foster children to attend extra classes. Furthermore, T2 repetitively employs the pragmatic marker 'you know' (lines 9 and 11) to further decrease the illocutionary force of her suggestion as it acts as a hedge (Lakoff, 1975), similar to 'I guess' and 'maybe' (lines 1 and 5). Perhaps, due to her social positioning as a teacher, she tries to reach out through the use of pragmatic marker and hedges makes her suggestion subtle as she might lack authority to effectuate the recommended tasks. Thus, T2's response falls in the stage of refocusing for wanting to improve foster children's academic performance.

\section{COMMISSIVE ACT}

Commissive act can also be found in the stage of refocusing in teachers' responses.

\section{Excerpt 11}

[1] T22: There are one or two students who they come and see me they say

[2] teacher / I don't have this enough money to buy uniform / for as I

[3] say this uniform bodies / the uniform itself is expensive / so when

[4] they these people come and see me / we will try to solve their problems /

In Excerpt 11, T22 ensures that she offers support to foster children when they complain to her about financial issue. The use of modal verb 'will' (line 4) commits T22's forthcoming action in which there is a 'possibility' (Leech, 1983) that she and the school committee are to solve the foster children's financial issue by helping them to buy cocurriculum uniforms. Her promise in assisting foster children with their financial issue is classified in the stage of refocusing as it shows her effort in trying to address these children's academic needs.

\section{DISCUSSION}

This section discusses the results of the findings. As depicted in Tables 5 and 6 , the stages of concern of teachers and caregivers were organised from the highest percentage to the lowest percentage.

TABLE 5. Findings of Stages of Concern of Teachers

\begin{tabular}{lc}
\hline Stages of Concern & $\begin{array}{c}\text { Percentages } \\
\text { for Teachers }\end{array}$ \\
\hline Refocusing & $65 \%$ \\
\hline Management & $50 \%$ \\
\hline Awareness & $42 \%$ \\
\hline Personal & $31 \%$ \\
\hline Informational & $19 \%$ \\
\hline Consequence & $15 \%$ \\
\hline Collaboration & $12 \%$ \\
\hline
\end{tabular}


Results show that stage of refocusing has the highest percentage in teachers' interview responses. Stage of management has the second highest percentage, followed by the stages of awareness, personal, informational, consequence and collaboration (see Table 5). Such findings illustrate teachers' high level of concern as they tried to help foster children by addressing the academic needs and issues via suggestions or actions in the stage of refocusing. For instance, teachers suggest using diagnostic assessment tests to identify foster children's weakness in the subjects. They also ensure foster children will receive financial support to purchase their co-curriculum uniforms. However, they encounter various challenges while trying to help these children. Teachers state that the lack of class time with the foster children is the issue they faced while addressing the academic needs of these children, which can be seen in the stage of management. Hall and Hord (1987) also record similar example in their study where time constraint is one of the challenges in making a better change. In the same stage, teachers also suggest or request for support in terms of financial aids to hire tutors for foster children.

Further, teachers are also aware of the foster children's poor academic performance. In the stage of awareness, teachers describe their awareness on the foster children's poor performance in the subjects these children are weak at. Such poor performance made the teachers to express their sympathies and concern about the foster children in the stage of personal.

Additionally, teachers also tried to explore the problems these children faced while in school. In the stage of informational, teachers state the way they find out more about the academic issue of foster children by approaching the children in class. Through their action, foster children reveal to the teachers that they have financial issue such as not being able to afford food. Moreover, teachers describe the negative impact of as peer influence or lack of attention towards the academic pursuits of foster children in the stage of consequence. Although not many teachers collaborate with the others to address foster children's academic needs as the stage of collaboration has the lowest percentage based on the data, those who collaborate with their colleagues ensure that they are to address foster children's poor academic performance, lack of attention and financial issues.

Table 6 shows that the stage of refocusing has the highest percentage in the caregivers' responses, followed by the stages of management, collaboration, awareness, personal, and consequence.

TABLE 6. Findings of Stages of Concern of Caregivers

\begin{tabular}{lc}
\hline Stages of Concern & $\begin{array}{c}\text { Percentages for } \\
\text { Caregivers }\end{array}$ \\
\hline Refocusing & $100 \%$ \\
\hline Management & $100 \%$ \\
\hline Collaboration & $67 \%$ \\
\hline Awareness & $50 \%$ \\
\hline Personal & $33 \%$ \\
\hline Consequence & $33 \%$ \\
\hline Informational & $0 \%$ \\
\hline
\end{tabular}

Similar to teachers, such results also indicate that caregivers have high level of concern towards foster children as they tried to help these children by addressing the academic needs and issues via suggestions or actions in the stage of refocusing. However, caregivers encountered various challenges while trying to help these children. In the stage of management, caregivers complain about the difficulties in addressing the academic needs and issues of foster children due to the lack of support from social welfare and financial issues in 
foster home. Besides, they request for financial support from social welfare agency to aid their financial issue at foster home such as hiring tutors for these children. Caregivers also collaborate with the others such as school teachers to monitor the academic progress of their foster children.

Besides, caregivers are more aware of the family and background documentation issues encountered by foster children than teachers, which can be seen in the stage of awareness. These documentation issues couple with foster children's poor academic performance have made caregivers to feel sad and sympathy for foster children when caregivers express their feelings at the stage of personal. Likewise, caregivers also assert that foster children's poor academic performance could be the consequence of their family issues, parents' negative influence or lack of attention in school.

Unlike teachers, caregivers skip the stage of informational as they are very much aware of the backgrounds and academic problems of foster children under their care. This finding signifies that stages of concern are not hierarchal as the participants' concerns at the subsequent stages were not influenced by their former stages, which concur with Anderson's (1997) and Straub's (2009) claims but contradicts Charambous' (2004) assumption on the hierarchical of stages of concern.

There are similarities and differences in regards to teachers and caregivers' concern towards foster children as they have different roles (i.e. service providers of education and caregiving). In the stage of awareness, it can be observed that teachers and caregivers are aware of the poor academic performance of foster children when they use representative act to describe the low level of comprehension in the subjects these children are weak at. However, caregivers are more aware of foster children's family issues or background documentation issues (e.g. birth certs or identity cards) than school teachers as they are very much involved in taking care of these children.

The teachers employ representative act with the verb saya tanya (I ask) to state that they approach the foster children in class in order to identify the problems they encounter in school, such as financial issues. Hence, their willingness to learn more about these children's conditions falls in the stage of informational. Unlike teachers, the responses of caregivers in this study are not found in the stage of informational. This is not surprising as given the fact that caregivers are constantly involved in taking care of foster children. Thus, they could be very much aware of the backgrounds and academic problems of these children.

Furthermore, in the stage of personal, teachers and caregivers' personal feelings can be observed when they express their sympathies and concern regarding foster children's poor academic performance using expressive act via the use of emotive adjectives kesian (sympathy) and also the verb 'feel' or rasa (saya rasa). Yet, apart from academic performance, caregivers also express their concern and sympathy towards their foster children's family problems in custody.

Representative act is also prominent in the stage of management where teachers describe issues faced while addressing the academic needs of foster children such as lack of class time. Whereas, caregivers employ representative act to complain about the lack of support from social welfare as well as financial issues in foster home. In the stage of refocusing, on the other hand, directive act can be observed when caregivers and teachers suggest or request for support in terms of financial aids to hire tutors for foster children.

Additionally, teachers use representative act particularly the word disebabkan (because, due to) in the stage of consequence to describe the impact that affects the academic pursuits of foster children such as peer influence or lack of attention in foster home. The caregivers, on the other hand, assert that parents' negative influence or lack of attention in school could be the reasons of foster children's poor academic performance. 
In the stage of collaboration, teachers employ modal verb 'will' in the form of commissive as well as the word bekerjasama (collaborate) or berbincang (discuss) to ensure that the problems encountered by foster children regarding poor academic performance, lack of attention and financial issues will be addressed with the support of their colleagues. Caregivers employ representative act to describe their act of collaborations with teachers to assist foster children with academic issues.

Finally, in the stage of refocusing, teachers use directive act particularly with modal verbs such as 'should', 'need', or 'must' to give suggestion on ways to improve the academic performance of foster children, such as using diagnostic assessment tests to identify foster children's weakness in the subjects. On the contrary, caregivers use directive act to request for financial support from social welfare agency to ease their financial issue at foster home. Teachers and caregivers also employ representative act to describe their actions in helping foster children such as monitoring foster children's academic progress. Commissive act was only used by teachers to ensure financial support is given to foster children, especially in terms of purchasing co-curriculum uniforms.

As shown in Table 7, the most salient speech act category found in teachers and caregivers' stages of concern is representative act. However, teachers and caregivers used the speech act categories in various ways.

TABLE 7. Findings of Categories of Speech Acts and Common Linguistic Features Used

\begin{tabular}{llcc}
\hline Categories of Speech Acts & Common Linguistic Features Used & Teachers & Caregivers \\
\hline Representative Act & To assert, describe, state, report, affirm & $81 \%$ & $100 \%$ \\
Directive Act & To suggest, request, insist & $46 \%$ & $83 \%$ \\
Expressive Act & To express & $27 \%$ & $33 \%$ \\
Commissive Act & To ensure, promise & $8 \%$ & $0 \%$ \\
Declarative Act & - & $0 \%$ & $0 \%$ \\
\hline
\end{tabular}

Teachers lack authority to address these children's academic needs such as monitoring their academic progress at foster home. Hence, during the interview, they reach out by using Searle's (1976) representative act to assert, report, describe and state about the academic problems foster children faced in school, which can be seen in the stages of awareness, personal and management. Not only do they reach out for support, teachers also employ Moghaddam's (2012) multiple intensifiers such as memang sangat (indeed really) and memang sentiasa (indeed always) to highlight on their deeds in assisting foster children in regards to their need for motivation, financial support and attention in school, which can be seen in the stage of refocusing. Such findings denote that they are trying to address the academic needs of foster children by highlighting the issues. Furthermore, in the stage of informational, teachers affirm that they have probed into the foster children's academic problems such as financial issue when they employ the verb tanya (ask) and the first person pronoun saya (I). Such response is similar to Hall and Hord's (1987) example of "I would like to know more about it". Teachers' collaboration with school personnel is evident via their use of the verb berbincang (discuss) and modal verb perlu (need) when they affirm that they work together as a team to address foster children's financial issue in the stage of collaboration. In the stage of consequence, teachers describe their concern on factors that affect the academic performance of foster children such as the lack of attention, lack of selfconfidence and peer influence, which could be seen from the conjunction 'because' or sebab (due to), verb buatkan (triggered), noun faktor (factor). On the contrary, caregivers mostly indicate their concern on the foster children's poor academic performance by stating, affirming and describing their collaborations with others to address these children's need for monitoring, tutors, and secure future plans. Verbs which are frequently used when indicating 
their collaborations are linked', 'meet up', 'come together' or 'work with them'. Moreover, the caregivers also report and describe the lack of financial support and tutors at foster home. To assert the necessity of providing foster children with tutors, caregivers used the intensifiers 'very' and memang (indeed), particle lah and modal verb 'have to'. The Malay particle lah in this study serves as an intensifier (Goddard, 1994) as the teacher was emphasising the importance of tuition class for foster children in Excerpt 10. This Malay particle is what makes it different than English speech act when voicing concern.

Directive act has the second highest percentage based on the findings. However, teachers used directive act more often than caregivers when they suggest ways to address foster children's lack of monitoring and motivation with modal verbs such as kena (have to), perlu (need to) and 'should'. Teachers also used mesti (must) to insist on the need to provide appropriate teaching aid and slower pace of teaching while teaching especially in classes which consist of students from foster homes. The modal verb mesti (must) shows that teachers are 'obligated' (Abdul Aziz Idris, 1980) to carry out certain tasks in school if they want to address the academic needs of foster children. Besides modal verbs, teachers also mitigate their suggestions via hedges, prolongation of pause filler /er:::/, tag questions and Malay particle kut in order to avoid any confrontation and sustain social harmony in workplace (Gom et al., 2015). The particle kut is a particle which commonly found in Malay speech. The particle kut is the short form of takut (Yap, Chor \& Wang, 2012, p. 339) which has the same function the hedge 'maybe' or 'perhaps' in English. Kut is somewhat similar to lah and they are not found in English mitigating devices (Fraser, 1980). Caregivers, on the other hand, used modal verbs 'need', perlu (need to) and 'should' to request for assistance in terms of financial and tutors for foster children are under their care. Similar to teachers, caregivers also employ pause filler /er/ and particle kut to mitigate their suggestions. Hence, the common linguistic features under directive act can be seen via the use of modal verbs perlu (need to) and 'should' as well as pause filler /er:::/ and particle kut.

Moreover, both teachers and caregivers' affective levels are identified through their use of expressive act in the stage of personal. They commonly utter 'I feel' and employ adjectives kesian (pity), sedih (sad), takut (worry), and kekecewaan (disappointment), followed by the intensifier memang (really), paling (most) and Malay particle lah to mark their sense of sympathy and concern.

Nevertheless, the data show that only teachers employ commissive act, which can be found in the stages of refocusing and collaboration. The teachers use the modal verb 'will' to promise to address the financial issues and need for attention of foster children in school, as according to Leech (1983), 'will' shows possibility of an action to be conducted in the near future.

Declarative act was not found in any stage of concern or in the teachers and caregivers' responses because they did not make any declaration during their interview sessions. Declarative act is incompatible during interviews because it requires additional lexical element such as 'hereby' or 'declare' in statements (Cutting, 2002, p. 16). These statements are also performed by certain authority in a specific context that triggers "immediate action from the utterance" (Stapleton, 2004, p. 15).

Results in this study indicate that speech act of concern does not belong to one category of speech act per se. Figure 3 shows the categories of speech act that emerged out of the findings in each stage of concern. Obviously, speech act of concern falls largely in the category of representative act, directive act, expressive act and commissive act. 


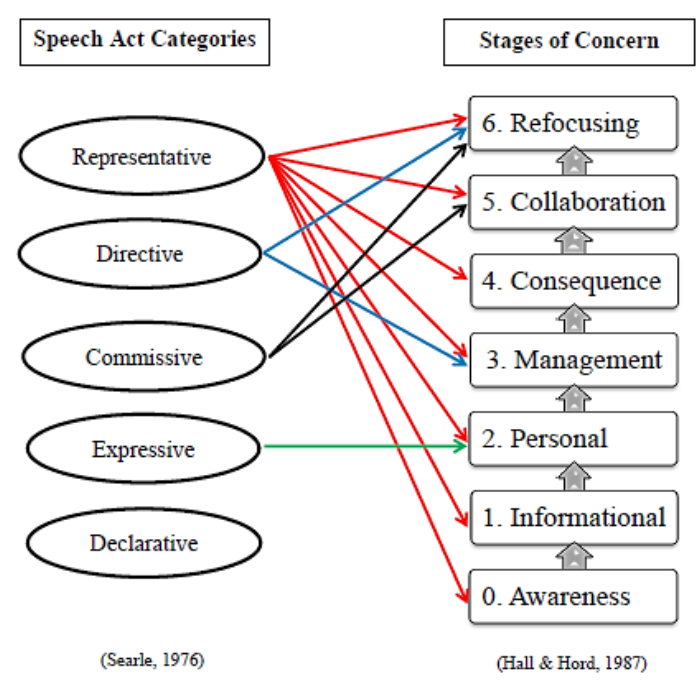

FIGURE 3. Results of the Combination of Speech Act Categories \& Stages of Concern

The findings show that three categories of speech act which are representative, directive and commissive were found in the stage of refocusing, the highest stage of concern. Moreover, two categories of speech act (i.e. representative act and commissive act) emerged in the stages of collaboration and management respectively; whereas, only one category of speech act (i.e. representative act) falls in the stages of awareness, informational, and consequence. Such a finding reveals the realisation patterns of speech act of concern not only can be identified through the teachers and caregivers' use of speech act categories, the degree of their concern can also be measured based on the stages of concern when compared with each other's use of linguistic features.

The most common linguistic features in representative act used by both teachers and caregivers are when they state, assert, describe, report, indicate and affirm; whereas, in directive act, the most common linguistic features are request and suggest. Besides, findings also indicate the number of years of working experience among teachers and caregivers in their work force did not show any effect on their concern towards foster children's needs, which in accordance with Straub's (2009) findings.

\section{CONCLUSION}

As demonstrated, the combination of speech act theory and stages of concern was applied for the analysis of language of concern in teachers and caregivers' interview responses. This study shows that concern is not only confined within the boundaries of one category of speech act (i.e. expressive act), but beyond the category of expressive act to representative act, directive act, and commissive act. Results show that the higher the stage is (i.e. refocusing), the more categories of speech act are found because teachers and caregivers voice concern in the hope of addressing the academic needs and issues of foster children. Stage of refocusing is the most prominent stage of concern in both teachers and caregivers' responses and it consists of three categories of speech act, which are representative, directive and commissive; whereas, the stages of management and collaboration each have two categories of speech act. On the other hand, the stages of awareness, informational, personal, and consequence only have one category of speech act respectively.

Teachers and caregivers are highly concerned about the academic performance of foster children as their responses are most prominent in the stage of refocusing. They use directive act to request or suggest the tasks they could not carry out. They also employ 
representative act to describe the actions taken in addressing the academic needs of these children. Nevertheless, teachers and caregivers encounter various difficulties while addressing the academic needs of foster children where they once again use representative act to describe the challenges they faced in the stage of management. Both teachers and caregivers express their feeling of sadness and sympathy for the foster children's poor academic performance via expressive act in the personal stage. While teachers use representative act to describe the way they approach the foster children to find out about their problems in the informational stage, caregivers state that they collaborate with tutors to address the academic problems of foster children under their care, as evident in the collaboration stage.

This study provides empirical evidence that Hall and Hord's (1987) stages of concern combined with Searle's (1976) speech act theory are highly applicable in analysing concern as well as in contributing to studies in linguistics. Language can be analysed based on the speech act categories and teachers and caregivers' degree of concern can be coded and analysed using the stages of concern. Hence, the analysis of concern from school teachers' and foster caregivers' perception of concern widens the scope of speech act categories. Such a contribution would allow future researchers to challenge existing boundaries in the area of speech acts.

\section{ACKNOWLEDGEMENT}

We would like to thank Postgraduate Research Fund (PPP) from University of Malaya for funding the project (A-502550025DA675).

\section{REFERENCES}

Abdul Aziz Idris. (1980). Modality in Malay. Kansas Working Paper in Linguistics. 5(1), 114.

Aziz, A., Maqsood, B., Saleem, T. \& Azam, S. (2018). The investigation of pragmatic transfer in the speech act of congratulations by Punjabi EFL learners. International Journal of English Linguistics. 8(6), 240-255.

Azizah Mohd. \& Nadhilah Abdul Kadir. (2012). Protection of children in Malaysia through foster care legislation and policy. International Journal of Social Sciences and Humanity Studies. 4, 63-72.

Anderson, S. E. (1997). Understanding teacher change: Revisiting the concerns based adoption model. Curriculum Inquiry. Vol. 27(3), 331-367.

Austin, J. L. (1962). How to Do Things with Words. Cambridge, MA: Harvard U.P.

Barnow, B. S., Buck, A., O'brien, K., Pecora, P., Ellis, M. L. \& Steiner, E. (2015). Effective services for improving education and employment outcomes for children and alumni of foster care service: correlates and educational and employment outcomes. Child \& Family Social Work. 20(2), 159-170.

Berger, L. M., Cancian, M., Han, E., Noyes, J. \& Rios-Salas, V. (2015). Children's academic achievement and foster care. Pediatrics. 135(1), 109-116.

Berhad, P. N. M. (2005). Child Act 2001 (Act 611). Percetakan Nasional Malaysia Berhad. Kuala Lumpur, Malaysia.

Bennett, J. (1982). Even if. Linguistics and Philosophy. 5(3), 403-418.

Bruskas, D. (2008). Children in foster care: A vulnerable population at risk. Journal of Child and Adolescent Psychiatric Nursing. 21(2), 70-77.

Carretero, M., Maíz-Arévalo, C. \& Martínez, M. Á. (2015). An analysis of expressive speech acts in online task-oriented interaction by university students. Procedia-Social and Behavioural Sciences. 173, 186-190. 
Chan, C. C. (2013). A comparative study on rumah kanak-kanak (children residential home) and rumah tunas harapan (foster home) in Malaysia: A child-centric perspective. Unpublished Ph.D thesis, National University of Singapore, Singapore.

Charambous, C. Y., Philippou, G. N. \& Kyriakides, L. (2004). Towards a unified model on teachers' concerns and efficacy beliefs related to a mathematics reform. In M. Hoines $\&$ A. Fuglestad (Eds.). Proceedings of the 28th Conference of the International Group for the Psychology of Mathematics Education (Vol. 2, pp. 199-206). Bergan, Norway.

Cutting, J. (2002). Pragmatics and discourse: A resource book for students. London: Routledge.

Fraser, B. (1980). Conversational mitigation. Journal of Pragmatics. 4(4), 341-350.

Fuller, F. (1969). Concerns of teachers: A developmental conceptualization. American Educational Research Journal. 6, 207-226.

Goddard, C. (1994). The meaning of lah: Understanding emphasis in Malay (Bahasa Melayu). Oceanic Linguistics. 33(1), 145-165.

Hall, G., George, A. \& Rutherford, W. (1979). Research \& Development Report No. 3032. Austin, TX: University of Texas, Research and Development Center for Teacher Education, The University of Texas.

Hall, G. \& Hord, S. (1987). Change in Schools: Facilitating the Process. New York: State University of New York Press.

Hall, G. \& Hord, S. (2006). Implementing Change: Patterns, Principles, and Potholes $\left(2^{\text {nd }}\right.$ ed.). Boston: Pearson Education, Inc.

Hord, S., Rutherford, W., Huling-Austin, L. \& Hall, G. (1987). Taking Charge of Change. Alexander, VA: Association for Supervision and Curriculum Development.

Kampf, Z. (2016). All the best! Performing solidarity in political discourse. Journal of Pragmatics. 93, 47-60.

Kreishan, L. (2018). Politeness and speech acts of refusal and complaint among Jordanian undergraduate students. International Journal of Applied Linguistics and English Literature. 7(4), 68-76.

Kuang, C. H. (2015). Functions of Malaysian condolences written in text messages. Social Sciences and Humanities. 23(1), 1-19.

Lakoff, R. (1975). Language and Woman's Place. New York: Harper and Row.

Laporan Statistik Jabatan Kebajikan Masyarakat, 2014 (Social Welfare Department Statistics Report, 2014). (2015, December 31). Retrieved 29 January 2016, from http://www.jkm.gov.my/file/Buku\%20JKM\%202014.pdf

Leech, G. (1983). Principles of Pragmatics. London and New York: Longman.

Ministry of Education. (2012). Malaysian Education Blueprint 2013-2025. Ministry of Education, Malaysia.

Moghaddam, M. (2012). Discourse structures of condolence speech act. Journal of English Language Teaching and Learning. 4(10), 105-125.

Newhouse, C. P. (2001). Applying the concerns-based adoption model to research on computers in classrooms. Journal of Research on Technology in Education. 33(5), 121.

Norazila Abd Aziz. (2017). Taking concerns into account: understanding the technology adoption process from the ESL teachers' point of view. The English Teacher. 14, 7689.

Olsen, R. F. \& de Montgomery, C. J. (2018). Revisiting out-of-home placed children's poor educational outcomes-Is school change part of the explanation? Children and Youth Services Review. 88, 103-113.

Parsa, H. \& Jariah Mohd Jan. (2016). Apology and non-apology strategies by Iranian Azerbaijani ESL students. Journal of Language \& Communication. 3(1), 61-71. 
Rezvani, E., Eslami-Rasekh, A. \& Dastjerdi, H. (2014). Investigating the effects of explicit and implicit instruction on Iranian EFL learners' pragmatic development: Speech acts of request and suggestion in focus. International Journal of Research Studies in Language Learning. 3(7), 1-12.

Rhee, S. H., Boeldt, D. L., Friedman, N. P., Corley, R. P., Hewitt, J. K., Young, S. E. \& Zahn-Waxler, C. (2013). The role of language in concern and disregard for others in the first years of life. Developmental Psychology. 49(2), 197-214.

Rhodes, K. V., Cerulli, C., Dichter, M. E., Kothari, C. L. \& Barg, F. K. (2010). I didn't want to put them through that: The influence of children on victim decision-making in intimate partner violence cases. Journal of Family Violence. 25(5), 485-493.

Searle, J. R. (1976). A classification of illocutionary acts. Language in Society. 5(1), 1-23.

Segermark, D. R. (2017). Students in foster care at risk of school failure: Addressing multiple needs. Unpublished master thesis, St Cloud State University, Minnesota.

Sharif, M., Yarmohammadi, L., Sadighi, F., Yamini, M. \& Bagheri, M. S. (2018). Iranian EFL learners' realisation of condolence: An interlanguage pragmatics study. Colombian Applied Linguistics Journal. 20(1), 105-119.

Shishavan, H. B. \& Sharifian, F. (2016). The refusal speech act in a cross-cultural perspective: A study of Iranian English-language learners and Anglo-Australian speakers. Language \& Communication. 47, 75-88.

Stapleton, L. E. (2004). Variation in the performance of speech acts in peninsular Spanish: Apologies and requests. (Doctoral dissertation, University of Louisiana, Mississippi). Retrieved from https://digitalcommons.lsu.edu/gradschool_dissertations/1335/

Straub, E. T. (2009). Understanding technology adoption: Theory and future directions for informal learning. Review of Educational Research. 79(2), 625-649.

Thang, S. M., Lin, L. K., Mahmud, N., Ismail, K. \& Zabidi, N. A. (2014). Technology integration in the form of digital storytelling: mapping the concerns of four Malaysian ESL instructors. Computer Assisted Language Learning. 27(4), 311-329.

Wang, W. (2014). Teachers' stages of concern and levels of use of a curriculum innovation in China: A case study. International Journal of English Language Teaching. 1(1), 2231.

Yap, F. H., Chor, W. \& Wang, J. (2012). On the development of epistemic 'fear' markers: An analysis of Mandarin kongpa and Cantonese taipaa. In W. Abraham \& E. Leiss (Eds.), Covert Patterns of Modality (pp. 312-342). Cambridge, UK: Cambridge Scholars.

Zetlin, A., Weinberg, L. \& Kimm, C. (2004). Improving education outcomes for children in foster care: Intervention by an education liaison. Journal of Education for Students Placed at Risk. 9(4), 421-429.

\section{ABOUT THE AUTHORS}

Cherish How is a Ph.D. student at the Faculty of Languages and Linguistics in University of Malaya. Her research interests are sociolinguistics and pragmatics, mainly in the area of speech acts and impoliteness.

Jariah Mohd Jan is an associate professor and the current dean of the Faculty of Languages and Linguistics in University of Malaya. She is specialised in the area of sociolinguistics, gender and power in relation to language, pragmatics and discourse. 